\title{
An appreciation of Professor John Lewis
}

\author{
D. Rollinson* \\ Department of Zoology, Natural History Museum, Cromwell Road, \\ London SW7 5BD, UK
}

(Received 6 October 2017; Accepted 6 October 2017)

The Journal of Helminthology is rapidly approaching its centenary year. It is a journal that has served the helminth community extremely well ever since it was founded by Professor R.T. Leiper way back in 1922. At that time, Professor Leiper was based at the London School of Hygiene and Tropical Medicine, and the emphasis was on the developing field of medical parasitology. Other distinguished leaders of our discipline followed as editors - Professor J. Buckley, Dr Sheila Wilmott and Dr Ralph Muller each left their mark and the scope of the journal was expanded to cover most aspects of helminthology. In 1994, Professor John Lewis took over as the fifth editor and skilfully guided the journal for the next 22 years before recently handing over to Professor Robert Poulin. John remains active as Editor Emeritus, and contributes and advises as required. In an age when new journals and editors seem to appear and often disappear with increasing frequency, it is surprising and strangely reassuring that there have only been six dedicated editors of the journal over such a long time span.

John Lewis will be known to all contributors of the journal as a most helpful and meticulous editor who has guided authors from first submission of their paper through to the publication stage. His in-depth knowledge of the subject has ensured that high-quality papers result; indeed, I am sure many authors will remain in his debt for the significant improvements to their original manuscript. He has also presented seminars on 'Scientific writing and publishing' on behalf of Cambridge University Press and CABI Publishing while on visits to overseas universities. Moreover, as detailed later, John has overseen and encouraged the publication of many special topics from international meetings and symposia.

This appreciation looks back at John's outstanding career both as an editor and research scientist; it highlights his many contributions to the study of parasitology, covering numerous aspects of the ecology and epidemiology of fish and mammalian parasites, as well as aquatic toxicology. Over his long and productive career John has been a teacher, mentor and friend to parasitologists around the world, and this article closes with just a few chosen comments from a small selection of his colleagues.

*E-mail: d.rollinson@nhm.ac.uk

\section{Early career}

John spent his school days (1949-1956) at Ystalyfera Grammar School in the Swansea valley in South Wales where he took the traditional science subjects of chemistry, zoology and botany. Those who have met John will know of his strong love of sport, and at school, rugby, squash and cricket were very much on the agenda. He captained the cricket team in the sixth form and found his chief rival was another Lewis (Tony) who captained the cricket team from neighbouring Neath Grammar School. No doubt many key matches were played out. Tony Lewis went on to captain Glamorgan and England but, fortunately for parasitology, John went on to study natural sciences, with an honours degree in zoology from University College of Wales, Aberystwyth.

In his third year at 'Aber' illness struck. En route with the rugby team to play Bangor University, he participated in a mass X-ray investigation on the diagnosis of tuberculosis and the X-ray revealed an active TB lesion. He spent 6 months as a patient confined to a TB ward with rest and regular treatment with streptomycin and picamycin. It is worth mentioning that $\mathrm{TB}$ is still today a major infection responsible for much mortality around the world. John slowly recovered and returned to Aberystwyth to complete his honours course, graduating in the summer of 1960. John went on to carry out his PhD (1960-63) under the supervision of Professor Gwendoline Rees FRS (known as Gwen, a past President and founder member of the British Society for Parasitology and the first Welsh woman to become a Fellow of the Royal Society). Many of her postgraduate students, like John, went on to have distinguished careers in parasitology.

John was funded by a SERC research studentship allocated to the Department of Zoology, commencing in September 1960. Gwen wanted him to pursue the research she was undertaking at that time on the taxonomy, histology and electron microscopy of trematodes in molluscs and fish. She was somewhat surprised that the research area he wished to pursue would focus on parasite ecology and epidemiology (he was strongly influenced by papers by Harry Crofton from Bristol during his zoology degree). He suggested to Gwen that a good ecological approach to parasitology would be to study infection dynamics in local small mammal populations, as these were readily obtained (by trapping) in woodland and grassland habitats. She eventually agreed, provided he would also 


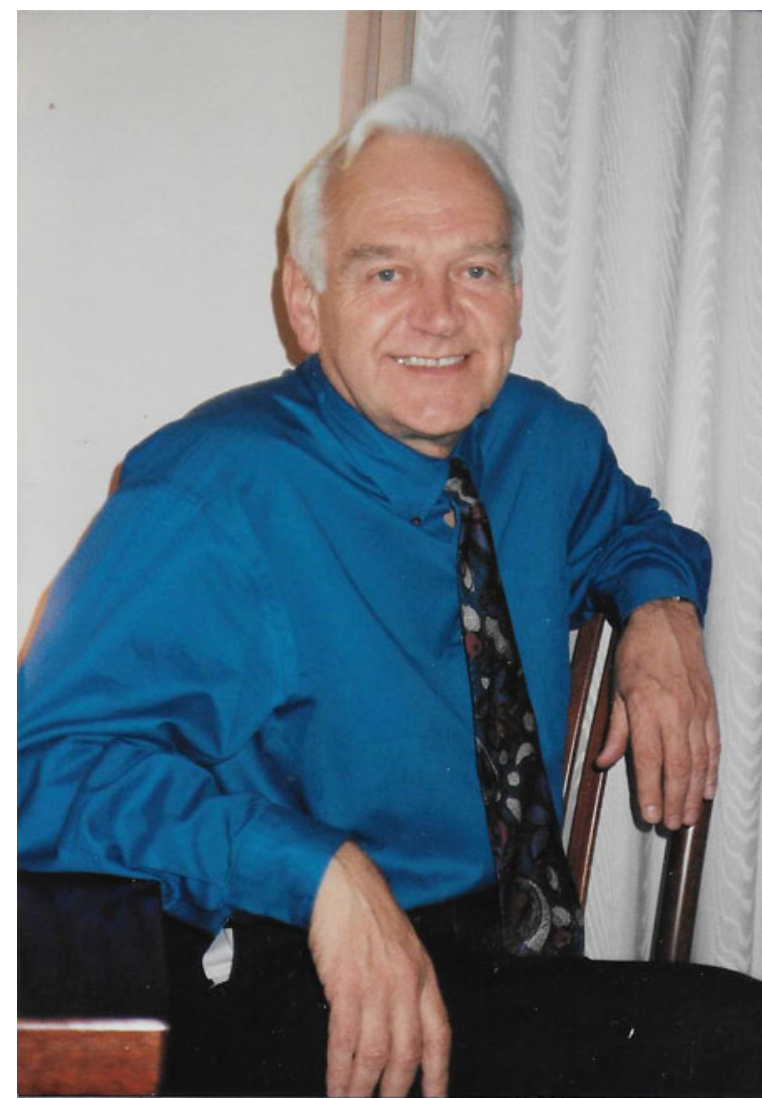

Fig. 1. John relaxing after his seminar on aquatic parasitology at the University of Vienna's field station, near Lake Neusiedlersee in southern Austria, 2002.

cover some taxonomy and ultrastructure of selected helminth species. Fortunately, this turned out to be an excellent approach as it enabled him to gain experience in electron microscopy, which at the time was an emerging technique. Gwen gave him all the support and encouragement required during those postgraduate years and in the final year of his $\mathrm{PhD}$ he was appointed Research Demonstrator in the Department of Zoology. Coincidentally, the external examiner of his $\mathrm{PhD}$ was Professor J. Buckley, London School of Hygiene and Tropical Medicine, and Editor-in-Chief of the Journal of Helminthology.

\section{University career}

John's skills were soon sought after and he was offered an Assistant Lectureship in Zoology at Royal Holloway, University of London during the summer of 1963 . He probably did not anticipate it at the time but he was to stay at Royal Holloway for the whole of his university career, being promoted to Lecturer in 1966, Senior Lecturer in 1981 and Professor of Zoology (University of London Chair) from 1992-2003. Throughout this period Royal Holloway was generous in awarding sabbatical leave or leave of absence for active researchers. This resulted at various times in John taking up visiting professorial positions at institutions such as the Department of Zoology, University of British Columbia, Vancouver, Canada; the Institute of Oceanography, University of Cumana, Venezuela; the Department of Zoology, University of Natal, Pietermaritzburg, South Africa; the Institute of Ecology and Conservation Biology, University of Vienna, Austria; the Institute of Biological Sciences, University of Malaya, Kuala Lumpur and the Faculty of Science, Universiti Malaysia Terengganu, Kuala Terengganu, Malaysia.

John contributed hugely to the university and university life at Royal Holloway. At various times he has been Departmental Tutor, Staff Appraiser, Chairman of the Postgraduate Research Committee, and Head of the Centre for Evolutionary and Environmental Biology. He was Dean of the Faculty of Science in the early 1980s, when the University of London was in the process of major re-structuring of various institutions. His sporting interests continued for many years; apart from being President of the Student Rugby Club, he was captain of the Staff Cricket team and also played for local clubs in Surrey.

John enjoys promoting his subject and encouraging students and postgraduates. For example at Royal Holloway he initiated teaching in parasitology and applied zoology, plus contributing to courses in marine biology, mammalogy and freshwater ecology, and to the MSc in environmental analysis and assessment taught jointly with Imperial College London.

Field biology and observation have been central to his work and, in conjunction with colleagues such as Robert Konecny (University of Vienna, Austria), Bernd Sures (Universities of Karlsruhe and Duisberg, Essen, Germany), Clive Kennedy (University of Exeter, UK) and colleagues from the Czech Republic, Hungary and Italy, he was instrumental in establishing a European postgraduate field course in fish parasitology, which was held intermittently during the 1990s and early 2000s at the University of Vienna's Biological Field Station adjoining Lake Neusiedlersee in southern Austria. John was also a primary contributor and coconvenor of the University of London's intercollegiate course 'Parasite ecology and epidemiology' with colleagues from King's College (Phil Whitfield, Frank Cox - see later comments) and Imperial College (Roy Anderson, Bill Hominick), which ran from the mid-1970s to 2003, when he formally retired. He was subsequently appointed Emeritus Professor of the University of London based at Royal Holloway and continues to lecture on epidemiology in the third-year course on biology of parasitic diseases.

John has made a truly magnificent contribution to postgraduate research and has supervised well over 40 PhDs, variously funded by NERC, SERC, SERC /CASE awards (with the Wellcome Foundation, Pfizer, Natural History Museum, King's College London, British Egg Authority, British Council, Thames Water) and AFRC, and many government scholarships from overseas (Austria, Bangladesh, Egypt, Kuwait, Malaysia, South Africa, Sudan and Qatar).

His work has always been of wide parasitological and ecological interest, and often central to environmental 


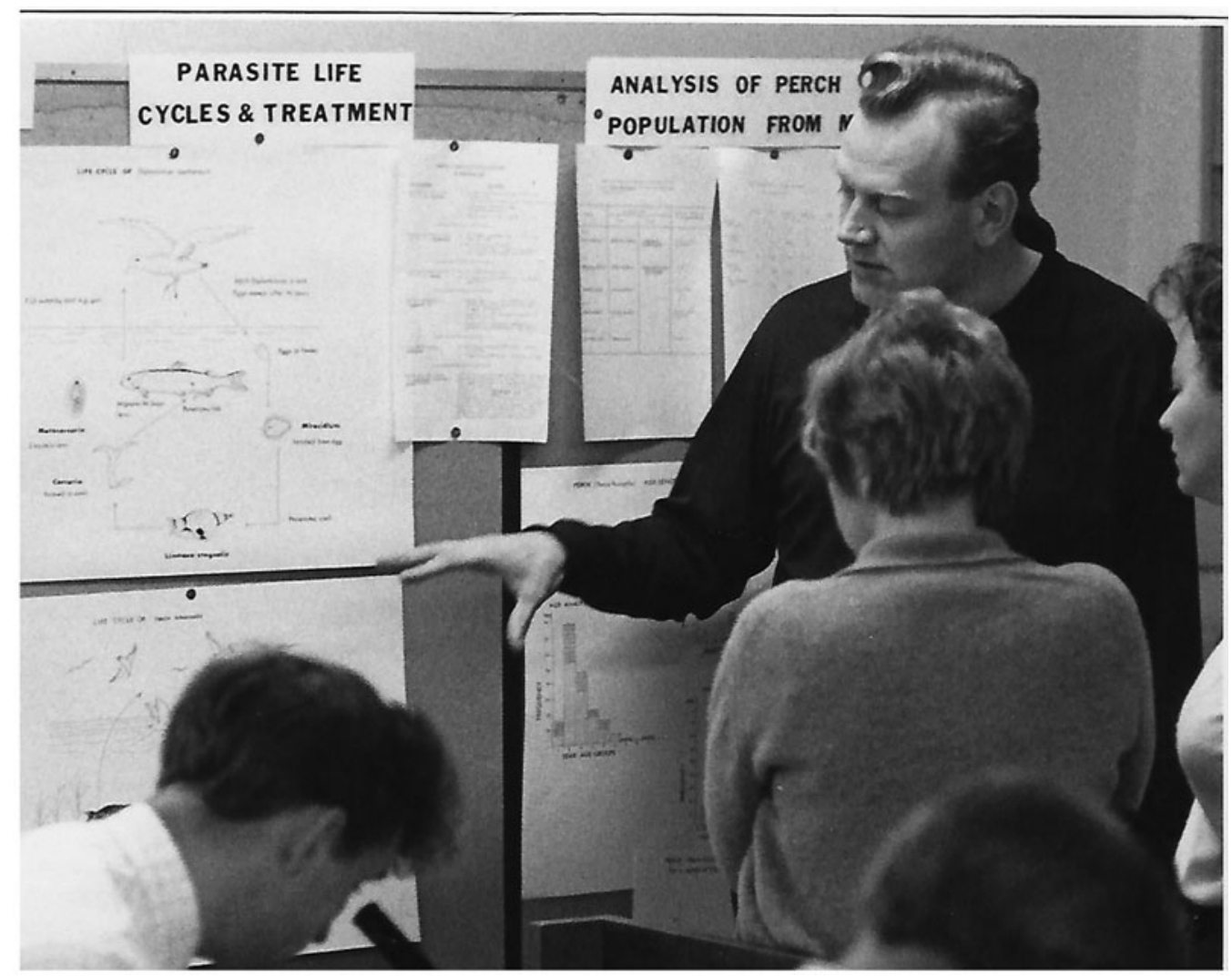

Fig. 2. John tutoring students in the identification and life cycles of fish parasites at Royal Holloway in 1973.

concerns. Not surprisingly, research funding has been forthcoming from many different sources including the UK research councils, industry, environmental agencies, water authorities, the Leverhulme Trust and many more funding bodies. John is also a founder and honorary member of the British Society of Parasitology, having served as ex officio member of the Council during the 1990s and early 2000s.

\section{Research \\ Mammalian parasitology}

Initial publications were generated from his $\mathrm{PhD}$ thesis, which commenced with a presentation at the First International Congress of Parasitology, Rome 1964, organized by the World Federation of Parasitologists (Lewis, 1964). John recalls that the session was chaired by R.L. Rausch (Alaska, USA) and the only other ecological paper given was by John Holmes (Edmonton, Canada) on factors influencing the trematode fauna of bats. The remainder mainly covered taxonomy, speciation, histochemistry and development. Participants included wellknown names such as B. Dawes, J.D. Smyth, H.W. Stunkard (American Museum), G.S. Nelson, A. Spasskii (USSR), D.F. Mettrick, D.A. Erasmus and M. Voge (Los Angeles).
During the remainder of the 1960s, studies carried out at Aberystwyth produced two descriptive and life-cycle papers in the Journal of Helminthology, two in Mammal Review and two ecological papers in the Journal of Zoology, London. Subsequent papers involved comparative studies undertaken in woodland areas in the Egham area, Surrey (Lewis \& Twigg, 1972), which is still cited. This appeared to be the first field study on the spatial distribution of helminths and serotypes of Leptospira in populations of small rodents, confirming clear evidence that parasites displayed random distribution or overdispersion. The latter process became fundamental to our understanding of parasite ecology and epidemiology, and, more recently, complementary measures from a reformulated negative binomial and inequality mathematical model have been combined to capture observed patterns of parasitic infections in mammalian hosts (Pal et al., 2008).

Further studies on spatial distribution in experimental hosts, such as laboratory mice, infected with the trichostrongyle nematode Nematospiroides dubius, now known as Heligmosomoides polygyrus (Behnke et al., 1991), also demonstrated overdispersion, with preference for establishment in the upper regions of the small intestine, thus likely to avoid competitive interactions with other parasites occupying the alimentary tract (Lewis \& Bryant, 1976). This led to other studies on nematode species within laboratory and wild rodents, especially the 
first-detailed descriptive (including ultrastructure) and life-cycle study of the oxyurid nematode Syphacia muris in laboratory rats, and rhythmic egg deposition by female worms (Lewis \& D'Silva, 1980, 1985). In addition, further studies on rhythmic behaviour (Kerboeuf \& Lewis, 1987) showed that intestinal helminths exhibit two types of circadian rhythms, either involving the migration of adult worms ( $S$. muris) within the alimentary tract or periodic release of eggs by female worms (H. polygyrus) to the exterior of the host, to maximize transmission efficiency. By modifying the feeding regimes of rodents, these rhythmic processes were shown to be linked directly with the digestive and defecating activities of the host, and neurohormonal mechanisms likely to be involved at least in the migratory behaviour of adult worms. Furthermore, studies showed that rhythmic egg output in $H$. polygyrus appears to be dependent upon parasite age and the population density of the host and parasite.

Continuing research on the population dynamics of helminth parasites in wild and laboratory rodents showed that host-helminth interactions are of importance in regulating both the abundance of parasites and rodent populations (Scott \& Lewis, 1987). This manuscript showed that parasite density in the case of intestinal nematodes and cestodes not only influences the ability of individual parasites to grow, reproduce and survive within the definitive rodent host, but also influences the ability of the infected host to survive and reproduce. The severity of the impact of such density-dependent processes is related to the pattern of parasite distribution within the rodent population. Furthermore, the component community structure of helminths in rodent populations such as the wood mouse Apodemus sylvaticus from habitats in SE England was shown to be seasonal and site-specific (Abu-Madi et al., 2000). Significant interactive effects on infection levels were primarily linked with host age and season. The structure of these component communities appeared to be influenced by interactions between species, and increasing burdens of the dominant trichostrongyle nematode $H$. polygyrus resulted in wood mice harbouring higher numbers of other helminth species (Behnke et al., 1999, 2005). Similar studies were carried out in urban populations of rats from Kuala Lumpur, Malaysia (Mohd Zain et al., 2012) and Doha, Qatar. However, the extremely hot and arid climate in the latter region reduced the survival of potential intermediate hosts, resulting in a monospecific infection of one helminth species, the cestode Hymenolepis diminuta, with cysticercoids occurring in the ectoparasitic rat flea, Xenopsylla astia (Abu-Madi et al., 2001).

In addition to extensive studies on the ecology of rodent parasites, continued funding from NERC in collaboration with the University of Bristol produced the first extensive study on the epidemiology of intestinal helminth parasites in rural and urban foxes in the UK (Richards et al., 1995). A wide range of helminth species were identified, some of which showed seasonal levels of infections, tending to peak in the spring/early summer following the birth of cubs in February and March. The dominant helminths included the hookworm Uncinaria stenocephala and the zoonotic ascarid nematode Toxocara canis. Prevalences of T. canis peaked at $76.0 \%$, suggesting a potential risk of human infection, especially with an increasing number of foxes entering the urban environment. Further zoonotic studies were also undertaken in feral hosts in the Middle East and Far East, where Toxocara cati was dominant in feral cat populations from Qatar (Abu-Madi et al., 2010) and Peninsular Malaysia (Mohd Zain et al., 2013). Research on the epidemiology of zoonotic infections continues to thrive, with funding from the University of Malaya and the Ministry of Health, Kuala Lumpur on implications of socio-demographic determinants and environmental characteristics on the transmission of parasitic infections, including Toxocara and Toxoplasma, in migrant workers of Peninsular Malaysia (Sahimin et al., 2016, 2017).

Apart from epidemiological studies, molecular approaches were undertaken in collaboration with Imperial College London, especially in the controversy about the identification of the trichostrongyle nematode $H$. polygyrus in wood and laboratory mice. Genomic variability and metabolic labelling confirmed differences between the wild and laboratory subspecies (Abu-Madi et al., $1994 a, b)$. Further analyses revealed high sequence divergences using ribosomal DNA internal transcribed spacers and the cytochrome $c$ oxidase subunit I (COI) gene, confirming that the wild species is likely to be $H$. polygyrus and the laboratory strain H. bakeri (Cable et al., 2006). Also in collaboration with Imperial College, in the case of the ascarid nematode Toxocara, a comparison of infective larvae from different isolates of $T$. canis and T. vitulorum by biosynthetic labelling of somatic and excretory-secretory (ES) proteins was undertaken for its potential in the specific diagnosis of human toxocariasis (Page et al., 1991).

\section{Aquatic parasitology}

John's interest in aquatic parasites commenced in $1971 / 72$ during sabbatical leave which he spent in the Department of Zoology, University of British Columbia (UBC), Vancouver, researching with Professor Jim Adams. His intention at that time was to initiate research at UBC in mammalian helminthology, but this would have been difficult to achieve in 1 year. Consequently, as Jim had close links with the Fisheries Research Board of Canada, he embarked on a physiological study of the frequently occurring dracunculoid nematode Philonema onchorhynchi in the sockeye salmon Oncorhynchus nerka, which migrates from the marine environment of the Pacific to freshwater inland lakes of British Columbia. It soon became evident that the survival of $P$. onchorhynchi in the body cavity of the migratory anadromous $O$. nerka is dependent upon the permeable nature of the nematode's body wall, allowing the worm to function as an 'osmometer', since the osmolarity of the blood plasma in sockeye salmon is known to decrease by at least $15 \%$ during migration. When viviparous worms pass out into the redd along with the eggs of female sockeye in the lake, osmotic entry of water into the worm occurs far quicker than ionic exchange, resulting in the release of larvae, which are then taken up by copepod intermediate hosts. Using biomedical techniques, experimental determination of the hydrostatic pressure in the pseudocoel of adult female worms indicated that the rate of increase in pressure shown by bursting worms in distilled water was correlated with the diameter of the nematode and 
independent of muscular contraction (Lewis et al., 1974). The end result is a massive explosion of up to a million larvae to infect copepods, from each female worm entering the lake water, thereby ensuring continuation of the life cycle.

On returning to the UK from Canada, John was approached by the National Rivers Authority (NRA) regarding the occurrence of fish mortalities in the Thames Region. His colleague Dr Roger Sweeting from the NRA reported a mass mortality of carp fry in a fish farm from the Cotswold area of Gloucestershire, and the parasite identified was the first record of the blood fluke Sanguinicola inermis in the UK. This species subsequently spread in fish farms and lakes throughout southern and central England with the practice of fish stock transfer from European waters and also within Britain.

Very little was known about this pathogenic fluke, but when funding was achieved from research councils and the NRA (Thames Region) much work was undertaken to determine the morphology, life cycle, migration, development and histopathology of S. inermis in carp (Kirk \& Lewis, 1992, 1993, 1994, 1996, 1998). Ultrastructural studies were also undertaken on the egg and miracidium of $S$. inermis and the distribution of serotonergic and peptidergic components within the cercarial nervous system (McMichael-Phillips et al., 1992a, b, 1996). The successful maintenance of $S$. inermis in the laboratory (Kirk \& Lewis, 1992) allowed further progress to be made on immunological aspects, including cellular responses of carp to eggs of $S$. inermis, changes to the cellular composition of the spleen and pronephros in infected carp, and in vitro polarization of carp leucocytes and adherence of these leucocytes to adult worms and cercariae of $S$. inermis (Richards et al., 1994a, b, 1996a, b).

The $S$. inermis-carp model represented the first experimental approach to evaluate the impact of aquatic pollution on cellular and immunological changes in a fish-macroparasite system, whereby ammonia appeared to suppress, while cadmium stimulated, the immune responses of fish to the blood fluke $S$. inermis (Schuwerack et al., 2001; Hoole et al., 2003; Lewis \& Hoole, 2003).

Two further examples of little-known fish parasites introduced into Britain from Europe included the ectoparasitic copepod Ergasilus, occurring on a variety of British freshwater fish, and the dracunculoid nematode Anguillicola crassus from the swimbladder of eels. The morphology and life-cycle stages of two ergasilid species, E. sieboldi and E. briani, were described in detail for the first time in collaboration with G.A. Boxshall of the Natural History Museum, London (Abdelhalim et al., 1991; Alston et al., 1993). In experimental infections undertaken on 1+- and 2+-year-old naïve rainbow trout in a clean lake site in Surrey, the transmission of E. sieboldi was shown to be temperature-related, with infections reaching a peak during the summer period.

The swimbladder nematode $A$. crassus was introduced into Europe with imported Japanese eels from SouthEast Asia in the early 1980s and was first reported from the UK in 1987. The nematode spread rapidly throughout European eels, aided by human trade activities and the natural vagility of eels in fresh water. The blood-feeding habits of $A$. crassus can cause extensive damage to the swimbladder of eels and a reduction of swimming performance. Experimental studies on the survival and transmission of $A$. crassus under estuarine and marine conditions confirmed that adult worms can tolerate seawater by osmoconformation with the blood plasma of the eel host. This suggests that $A$. crassus is capable of survival and reproduction for long periods, with potential to impair the success of the eel spawning migration to the Sargasso Sea (Kirk et al., 2000a, b, 2002). This, together with exposure to environmental contaminants, is likely to have a significant impact on eel conservation.

Apart from A. crassus, studies on the intestinal macroparasite communities in eels from two rivers in the south of England showed that high infracommunity diversity in this fish host was likely to be a simple stochastic reflection of component community diversity. The occurrence of a nested (non-random) species composition in eels showed a graded abundance between parasite species, whereas patterns of infracommunity species richness in eels were found to share a fundamental similarity with those of birds and mammals (Norton et al., 2003, 2004).

Study of the impact of heavy-metal pollution on the diversity and richness of fish macroparasites was undertaken with the University of Vienna, Austria and the University of Karlsruhe, Germany, to determine whether or not macroparasites could act as indicators of heavymetal pollution. Long-term studies were undertaken on helminth species in the cyprinid barbel, Barbus barbus, exposed to known levels of cadmium, lead and zinc in two river sites in Austria. However, the choice of diet tended to have more influence on parasite diversity/abundance than pollution, although the frequently occurring acanthocephalan Pomphorhynchus laevis was found to be a most sensitive indicator, accumulating significantly higher levels of metals than its host (Schludermann et al., 2003). Several studies were also undertaken on the effects of heavy-metal pollution on the transmission of larval digeneans in the freshwater snails Lymnaea peregra and L. stagnalis. Relatively low levels of cadmium and zinc significantly reduced the emergence and survival of miracidia and cercariae of Diplostomum spathaceum and Echinoparyphium recurvatum (Morley et al., 2003a, b, 2004). In addition, long-term studies have shown how host size and seasonality influence the emergence of cercariae from aquatic gastropods, with particular emphasis on thermodynamics and temperature stress on development and emergence of trematodes in ectothermic and endothermic hosts (Morley \& Lewis, 2004, 2013, 2014). Further studies on climate change in Yucatan, Mexico have shown how temporal patterns of temperature and rainfall influence the mean abundance and aggregation of helminth parasites in fish. In addition, rainfall patterns in this tropical region have resulted in changes in the prevalence of infection in aquatic hosts. The incorporation of stochastic events, such as storms and hurricanes, into predictive models was shown to be crucial for understanding the potential effects of global climate change on infection parameters of tropical parasites (Pech et al., 2010; Vidal-Martinez et al., 2014).

\section{Aquatic toxicology}

Research output in this field emerged from earlier studies on the ultrastructure and ecology of fish parasites. John 
demonstrated for the first time how electron microscopy, and in particular scanning electron microscopy (SEM), could be used as a diagnostic tool to detect specific patterns of surface damage on the gills of freshwater fish (Alazemi et al., 1996). This technique, using deployed fish, was used for detecting pollutants and monitoring water quality in lakes and rivers following pollution incidents. In conjunction with the Environment Agency UK, University of Lancaster and University of Warwick, techniques such as SEM, high-pressure liquid chromatography, mass spectrometry and molecular approaches, have shown that microbial toxins, especially from strains of actinobacteria (e.g. Streptomyces griseus) are responsible for massive fish mortalities in many aquatic habitats throughout the UK (Lewis et al., 2009, 2012).

Novel biosensing studies on freshwater mormyrid fish of the genus Gnathonemus showed that behavioural and electrical responses of these fish to a broad spectrum of low-level concentrations of toxic chemicals, such as cyanide, heavy metals and pesticides, can be used as biosensors of environmental pollution. Correlations were shown between the rate of pulsing, characterized by patterns of electric organ discharge, and water quality (Lewis et al., 1994). Such a system, which showed considerable potential for real-time monitoring of toxic chemicals at river intake sites, was funded by Thames Water, and a prototype was developed for use in the tropical waters of eastern Malaysia, in collaboration with the Universiti Malaysia Terengganu, Kuala Terengganu and substantial funding from Petronas Oil.

In South Africa, using assays in histopathology and physiology, the freshwater crab Potamonautes warreni was shown to be a bioindicator of heavy-metal contamination, especially waterborne cadmium (with Schuwerack et al., 2001). In North Africa, in association with the Institute of Graduate Studies in Alexandria, studies on direct toxicity assessment of heavy metals and pesticides were undertaken using chironomid larvae exposed to chemical-spiked sediments, with the view to remediate parts of the polluted Lake Maryut (Ibrahim et al., 1998; Kheir et al., 2001).

\section{Selected topics from special symposia /meetings during his time as Editor-in-Chief}

In the early stages after taking over the Editorship, John introduced special themes to the Journal of Helminthology for the first time. Some selected topics / venues include the following.

$$
\text { June } 2001 \text { - Vol. } 75
$$

Special theme on 'Toxocara and toxocariasis' based on papers from EMOP VIII, Poznan, Poland, September 2000, arranged with Professor Z. Pawlowski, Poznan University of Medical Sciences. Some examples are:

Zhu XQ, Gasser RB, Chilton NB and Jacobs DE. Molecular approaches for studying ascaridoid nematodes with zoonotic potential with emphasis on Toxocara species. pp. 101-108.

Taylor MRH. The epidemiology of ocular toxocariasis. pp. 109-118.
Fenoy $S$ et al. Animal models in ocular toxocariasis. pp. 119-124.

Holland CV and Cox DM. Toxocara in the mouse: a model for parasite-altered behaviour. pp. 125-136.

Pinelli E et al. Toxocariasis and allergic asthma in murine models. pp. 137-140.

Pawlowski Z. Toxocariasis in humans: clinical expression and treatment dilemma. pp. 299-306 (this paper missed the deadline for the June issue but was part of the December issue).

$$
\text { June } 2003 \text { - Vol. } 77
$$

Papers from a special meeting on 'Immunity to intestinal parasitic infections' arranged with Derek Wakelin and Jerzy Behnke at the University of Nottingham, July 2002. Some examples are:

Else KJ and de Schoolmeester ML. Immunity to Trichuris muris in the laboratory mouse. pp. 95-98.

Behnke J et al. (includes D. Wakelin). Chasing the genes that control resistance to gastrointestinal nematodes. pp. 99-110.

Ben-Smith A et al. The relative involvement of Th1 and Th2 associated immune responses to the expulsion of a primary infection of Heligmosomoides polygyrus in mice of differing response phenotype. pp. 133-146.

$$
\text { September } 2005 \text { - Vol. } 79
$$

Papers from the EMOP IX, Valencia, Spain, July 2004 arranged with Santiago Mas-Coma and David Rollinson in memory of Dr Kenneth E. Mott, formerly Chief of the Schistosomiasis and Intestinal Parasites Unit, WHO, Geneva, Switzerland. Some examples are:

Southgate VR et al. Towards control of schistosomiasis in sub-Saharan Africa. pp. 181-186.

Theron A and Coustau C. Are Biomphalaria snails resistant to Schistosoma mansoni? pp. 187-192.

Webster BL et al. The interaction of Schistosoma haematobium and S. guineenis in Cameroon. pp. 193-198.

Mas-Coma S. Epidemiology of fascioliasis in human endemic areas. pp. 207-216.

Hillyer GV. Fasciola antigens as vaccines against fascioliasis and schistosomiasis. pp. 241-248.

Barques MD and Mas-Coma S. Reviewing lymnaeid snails of fascioliasis by ribosomal DNA sequence analysis. pp. 257-268.

$$
\text { June } 2006 \text { - Vol. } 80
$$

Papers from the Black Forest Symposium on 'Environmental and ecological parasitology: the impact of global change' held in Freudenstadt, Germany, April 2005, arranged with Horst Taraschewski and Bernd Sures, University of Karlsruhe. Some examples are: 
Taraschewski H. Hosts and parasites as aliens. pp. 99-128.

Morley NJ et al. Pollutant-induced effects on immunological and physiological interactions in aquatic hosttrematode systems: implications for parasite transmission. pp. 137-150.

Hudson PJ et al. Climate disruption and parasite-host dynamics: patterns and processes associated with warming and the frequency of extreme climatic events. pp. 175-182.

Poulin R and Mouritsen KN. Climate change, parasitism and the structure of intertidal systems. pp. 183-192.

\section{June 2007 - Vol. 81}

Papers on 'Parasites as biological tags and responses of their aquatic hosts to environmental change' presented at ICOPA XI, Glasgow, August 2006, with assistance from Ken MacKenzie, University of Aberdeen. Some examples are:

Mattiucci S et al. Distribution of Anisakis larvae, identified by genetic markers, and their use for stock characterization of demersal and pelagic fish from European waters: an update. pp. 117-128.

Khan RA. Effects of environmental change on parasites of Atlantic cod (Gadus morhua) as bioindicators of populations in the north-western Atlantic Ocean. pp. 129-136.

Campbell $\mathbf{N}$ et al. Spatial and temporal variations in parasite prevalence and infracommunity structure in herring (Clupea harengus) caught to the west of the British Isles and in the North and Baltic Seas: implications for fisheries science. pp. 137-146.

Baker TG et al. Stock identification of the sciaenid fish Micropogonias undulatus in the western North Atlantic Ocean using parasites as biological tags. pp. 155-168.

In addition, during John's editorship, and with support from Professor Mark Viney as Deputy Editor during 2013-2016, the Journal of Helminthology published three papers from ICOPA (Mexico) in 2015 plus special issues in March 2017 on 'Parasitic helminths from Latin America and the Caribbean' and July 2017 on 'Arctic parasitology' from invited papers given at EMOP XII in Turku, Finland, July 2016.

\section{Thoughts and comments from selected colleagues}

\section{Dr Siti Nursheena Mohd Zain}

Our paths crossed when John played a role as my $\mathrm{PhD}$ supervisor, beginning from 1994 until 1998, in mammalian parasitology at the School of Biological Sciences, Royal Holloway. I am indebted to him for his invaluable advice and encouragement throughout this period and up until today. Upon my return to Malaysia, John continued to mentor me in my research endeavours. We were jointly awarded a 3-year British Council Committee for International Co-operation in Higher Education (CICHE) grant in 2000 to study the role of rodents and feral carnivores in the transmission of zoonotic parasite infections in Malaysia, and to establish the first epidemiological database on parasites of rodents in Malaysia. John continues to be a strong supporter of all my research pursuits as an international co-researcher. In addition, with his expert editing skills, we have co-authored many papers together over the years. Presently, we are actively collaborating in research on parasitic infections in migrant workers in Malaysia. I am truly blessed to have him as a mentor, teacher and a friend.

\section{Dr Ruth Kirk}

I first started working with John in 1984 on a PhD studentship on Sanguinicola inermis, a blood fluke in carp, which was causing severe mortalities in British carp farms. We developed a protocol to maintain the life cycle in the laboratory, enabling further research on the parasite biology and host immunological responses. Working at Royal Holloway was particularly enjoyable as views from the Department of Zoology windows featured a herd of Jacob's sheep, chickens, a goat and a tame fox called Basil. Each September was spent on the University of London Parasite Epidemiology field course at the Silwood Park campus of Imperial College, where many parasitological tales were swapped between John, Don Bundy, Phil Whitfield and Roy Anderson. John and I established a Fish Parasitology and Pathology Consultancy at Royal Holloway, which delivered research and services to the Environment Agency and fisheries industry. We then worked with Clive Kennedy at Exeter University on Anguillicoloides crassus, a pathogenic swimbladder nematode of European eels, generating important information on the transmission and survival of the parasite in fresh- and seawater eels. It was always a pleasure to work with John as he encouraged me to actively drive projects and gave me much helpful advice on disseminating knowledge in research and teaching.

\section{Professor Frank Cox}

From the mid-1960s to the mid-1970s King's College London and Imperial College (IC) London ran a joint parasitology field course at Slapton Ley in Devon. In 1976, IC and King's decided to make more use of their own field centres at Silwood Park in Berkshire and Rogate in Sussex, respectively. King's required a new partner and teamed up with Royal Holloway College. John brought particular expertise because of his encyclopaedic knowledge of mammalian and fish parasites, and the course became a great success. Both students and staff worked very hard, but also relaxed to such an extent that in 1977 the local pub, The White Horse (frequented by the discredited entertainer, Garry Glitter), ran out of draft beer. The photograph below shows John, on the right, Frank Cox to his left, Roy Anderson to his left and Phil Whitfield with the striped sweater. 


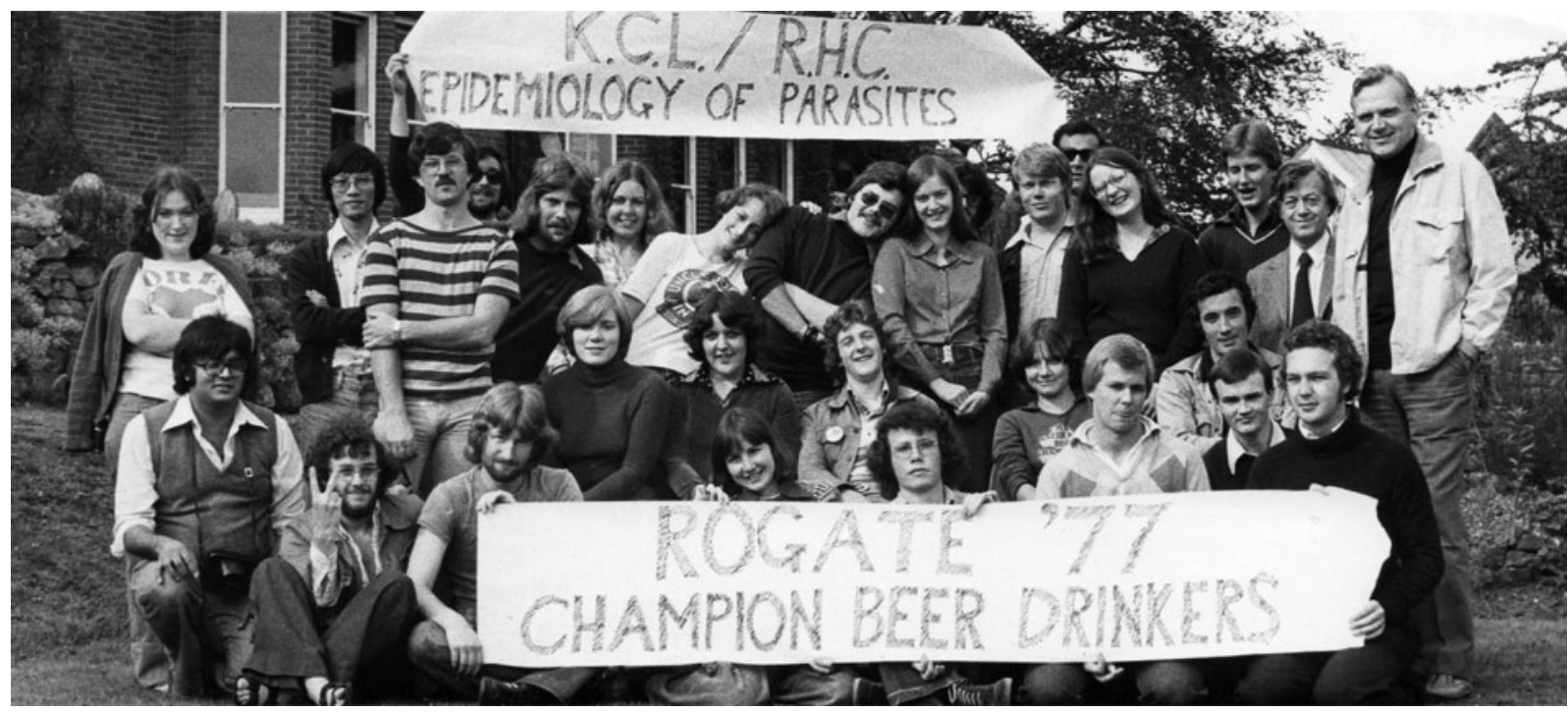

Fig. 3. Parasite ecology and epidemiology field course, Rogate, Sussex in 1977.

\section{Professor Jerzy Behnke}

I first met John in person when he sat before me as my PhD examiner in 1974. I survived, and since then we have worked together on and off over the intervening decades on a number of different projects. One of our main interests has been in the helminth parasites of British rodents and, together with his PhD students Marawan AbuMadi and Sheena Mohd Zain, we have retained that interest to the present time. John has acted as a very thorough external examiner for our undergraduate students and also for several $\mathrm{PhD}$ students from Nottingham. His warm, diplomatic and relaxed style of examining has put many a student at ease and made the whole process of viva examination enjoyable and memorable for the candidates involved. For all of his hard work, my colleagues and I are deeply grateful. His insight and depth of knowledge in parasitology, but equally ecology and the environment, has been much valued and appreciated. His advice and contribution to our research has always been of great value and, on more than one occasion, has opened our eyes to aspects that we had missed altogether. John has been an extremely successful and accomplished editor of the Journal of Helminthology, and his leadership in this role is, and will be, much valued for years to come. I wish John a very happy and long retirement, and hope that even in retirement his wisdom will continue to hone our collaborative research projects for years ahead.

\section{Professor Chris Arme}

I first met John in our student days. Welsh parasitology produced a strong cohort of colleagues, many under the guidance of Gwen Rees, who have subsequently gone on to senior positions. Under John's tutelage, I learnt a number of Aberystwyth traditions. One was a walk by the sea, literally to kick the bar on the shore, and another was joining John and many other friends in rather overdoing things at the sherry receptions at British Society for Parasitology meetings. After I moved to a Chair at Keele, Dave Hoole joined my embryonic group on fish parasites. At the time, I didn't know the extent to which this would renew our friendship and also lead to rewarding research collaborations.

\section{Professor David Hoole}

Shortly after I joined Chris Arme's Parasitology Research Group, John contacted me to discuss collaboration on immunological aspects of an AFRC (now BBSRC) grant application. The grant was subsequently awarded and was the start of a friendship and joint studies that are still active today. John assisted in the work of several of my PhD students and post-doctoral workers, to which he brought not only his many scientific skills but his care and mentorship of young parasitologists. Our work involved several visits to Royal Holloway, during which one of the most difficult tasks was surviving John's hospitality. One of my career highlights was when John and his wife accepted my invitation to attend my inaugural lecture followed by the Vice Chancellor's dinner.

\section{In conclusion, closing words from Chris Arme and David Hoole}

John has given willingly of his time, knowledge and friendship to many junior colleagues, both in the UK and overseas. Editing the journal was only part of his life, and his retirement will doubtlessly free-up time to continue his work in parasitology. Given his special interest in the developing world, he will no doubt wish to keep his passport up to date and to continue as an outstanding ambassador for our discipline.

It is hard to imagine the Journal of Helminthology without John as Editor. You have some big boots to fill, Robert! 


\section{References}

Abdelhalim, A.I., Lewis, J.W. \& Boxsall, G.A. (1991) The life cycle of the parasitic copepod Ergasilus sieboldi. Journal of Natural History 25, 559-582.

Abu-Madi, M.A., Pleass, R.J. \& Lewis, J.W. (1994a) Metabolic labelling of wild and laboratory subspecies of the trichostrongyle nematode Heligmosomoides polygyrus. Veterinary Parasitology 55, 235-243.

Abu-Madi, M.A., Reid, A.P., Lewis, J.W. \& Hominick, W.M. (1994b) Genomic variability within laboratory and wild subspecies of Heligmosomoides polygyrus. Journal of Helminthology 68, 93-96

Abu-Madi, M.A., Behnke, J.M., Lewis, J.W. \& Gilbert, F. S. (2000) Seasonal and site specific variation in the component community structure of intestinal helminths in Apodemus sylvaticus from three contrasting habitats in south-east England. Journal of Helminthology 74, 7-15.

Abu-Madi, M.A., Lewis, J.W., Mikhail, M., El-Nagger, M.E. \& Behnke, J.M. (2001) Monospecific helminth and arthropod infections in an urban population of brown rats from Doha, Qatar. Journal of Helminthology 75, 313-320.

Abu-Madi, M.A., Behnke, J.M., Prabhaker, K.S., AlIbrahim, R. \& Lewis, J.W. (2010) Intestinal helminths of feral cat populations from urban and suburban districts of Qatar. Veterinary Parasitology 168, 284-292.

Alazemi, B.M., Lewis, J.W. \& Andrews, E.B. (1996) Gill damage in the freshwater fish Gnathonemus petersii (family: Mormyridae) exposed to selected pollutants: An ultrastructural study. Environmental Science and Technology 17, 225-238.

Alston, S., Boxshall, G.A. \& Lewis, J.W. (1993) A redescription of adult females of Ergasilus briani Markewitsch 1933 (Copepoda: Poecilostomatoida). Systematic Parasitology 24, 217-227.

Behnke, J.M., Keymer, A. \& Lewis, J.W. (1991) Heligmosomoides polygyrus $=$ Nematospiroides dubius. Parasitology Today 7, 177-179.

Behnke, J.M., Lewis, J.W., Zain, S.N.M. \& Gilbert, F.S. (1999) Helminth infections in Apodemus sylvaticus in southern England: interactive effects of host age, sex and year on the prevalence and abundance of infections. Journal of Helminthology 73, 31-44.

Behnke, J.M., Gilbert, F.S., Abu-Madi, M.A. \& Lewis, J. W. (2005) Do the helminth parasites of wood mice interact? Journal of Animal Ecology 74, 982-993.

Cable, J., Harris, P.D., Lewis, J.W. \& Behnke, J.M. (2006) Molecular evidence that Heligmosomoides polygyrus from laboratory mice and wood mice are separate species. Parasitology 133, 111-122.

Hoole, D., Lewis, J.W., Schuwerack, P.M.M., Chakravarthy, C., Shrive, A.K., Greenhough, T.J. \& Cartwright, J.R. (2003) Inflammatory interactions in fish exposed to pollutants and parasites: a role for apoptosis and $\mathrm{C}$ reactive protein. Parasitology 126, S71-86.

Ibrahim, H., Kheir, R., Helmi, S., Lewis, J.W. \& Crane, M. (1998) Effects of organophosphorus, carbamate, pyrethroid and organochlorine pesticides, and a heavy metal on survival and cholinesterase activity of Chironomus riparius Meigen. Bulletin of Environmental Contamination and Toxicology 60, 448-455.
Kerboeuf, D. \& Lewis, J.W. (1987) Rhythmic behaviour of intestinal helminths in rodents. Mammal Review 17, 127-134.

Kheir, R., Ibrahim, H., Lewis, J.W., Callaghan, A. \& Crane, M. (2001) Comparison of acetylcholinesterase and glutathione S-transferase activity in Chironomus riparius Meigen exposed to chemical-spiked sediments. Bulletin of Environmental Contamination and Toxicology 66, 603-610.

Kirk, R.S. \& Lewis, J.W. (1992) The laboratory maintenance of Sanguinicola inermis Plehn, 1905 (Digenea: Sanguinicolidae). Parasitology 104, 121-127.

Kirk, R.S. \& Lewis, J.W. (1993) The life-cycle and morphology of Sanguinicola inermis Plehn, 1905 (Digenea: Sanguinicolidae). Systematic Parasitology 25, 125-133.

Kirk, R.S. \& Lewis, J.W. (1994) The distribution and host range of species of the blood fluke Sanguinicola in British freshwater fish. Journal of Helminthology 68, 315-318.

Kirk, R.S. \& Lewis, J.W. (1996) Migration and development of the blood fluke Sanguinicola inermis Plehn, 1905 (Trematoda: Sanguinicolidae) in carp, Cyprinus carpio L. Parasitology 113, 279-285.

Kirk, R.S. \& Lewis, J.W. (1998) Histopathology of Sanguinicola inermis infection in carp, Cyprinus carpio. Journal of Helminthology 92, 33-38.

Kirk, R.S., Lewis, J.W. \& Kennedy, C.R. (2000a) Survival and transmission of Anguillicola crassus Kuwahara, Niimi \& Itagaki, 1974 (Nematoda) in sea water eels. Parasitology 120, 289-295.

Kirk, R.S., Kennedy, C.R. \& Lewis, J.W. (2000b) Effect of salinity on hatching, survival and infectivity of Anguillicola crassus (Nematoda : Dracunculoidea) larvae. Diseases of Aquatic Organisms 40, 211-218.

Kirk, R.S., Morritt, D., Lewis, J.W. \& Kennedy, C.R. (2002) The osmotic relationship of the swim bladder nematode Anguillicola crassus with sea water eels. Parasitology 124, 339-347.

Lewis, J.W. (1964) An ecological analysis of the helminth fauna of British small mammals. Helminths of mammals: cestodes and trematodes. First International Congress of Parasitology, Rome, C2, 72.

Lewis, J.W. \& Bryant, V. (1976) the distribution of the trichostrongylid nematode Nematospiroides dubius within the small intestine of laboratory mice. Journal of Helminthology 50, 163-171.

Lewis, J.W. \& D'Silva, J. (1980) Rhythmic egg deposition by the oxyurid nematode Syphacia muris in the rat. Journal of Zoology, London 191, 429-433.

Lewis, J.W. \& D'Silva, J. (1985) The life cycle of Syphacia muris (Nematoda: Thelaziidae) in the laboratory rat. Journal of Helminthology 60, 39-46.

Lewis, J.W. \& Hoole, D. (2003) Parasitism and environmental pollution: parasites and hosts as indicators of water quality. Parasitology 126, S1-S109.

Lewis, J.W. \& Twigg, G.I. (1972) A study of the intestinal parasites of small rodents from woodland areas in Surrey. Journal of Zoology 166, 61-77.

Lewis, J.W., Jones, D.R. \& Adams, J.R. (1974) Functional bursting by the dracunculoid nematode Philonema onchorhynchi. Parasitology 69, 417-427.

Lewis, W., Kay, A.N. \& Hanna, S. (1994) Responses of electric fish (family Mormyridae) to chemical changes 
in water quality. III. Heavy metals. Environmental Science and Technology 15, 969-978.

Lewis, J.W., Morley, N.J., Drinkall, J., Jamieson, B.J., Wright, R. \& Parry, J.D. (2009) Toxic effects of Streptomyces griseus spores and exudates on the gill pathology of freshwater fish. Ecotoxicology and Environmental Safety 72, 173-181.

Lewis, J.W., Morley, N.J., Challis, G.I., Ahmed, M., Wright, R. \& Morritt, D. (2012) Structural changes in freshwater fish and chironomids exposed to bacterial exotoxins. Ecotoxicology and Environmental Safety 80, 37-44.

McMichael-Phillips, D., Lewis, J.W. \& Thorndyke, M.C. (1992a) The ultrastructure of the egg of Sanguinicola inermis Plehn, 1905 (Digenea: Sanguinicolidae). Journal of Natural History 26, 895-904.

McMichael-Phillips, D., Lewis, J.W. \& Thorndyke, M.C. (1992b) Ultrastructural studies on the miracidium of Sanguinicola inermis Plehn, 1905 (Digenea: Sanguinicolidae). Parasitology 105, 435-443.

McMichael-Phillips, D., Lewis, J.W. \& Thorndyke, M.C. (1996) The distribution of neuroactive substances within the cercaria of Sanguinicola inermis. Journal of Helminthology 70, 309-317.

Mohd Zain, S.N., Behnke, J.M. \& Lewis, J.W. (2012) Helminth communities from two urban rat populations in Kuala Lumpur, Malaysia. Parasites and Vectors $5,47$.

Mohd Zain, S.N., Sahimin, N., Pal, P. \& Lewis, J.W. (2013) Macroparasite communities in stray cat populations from urban cities in Peninsular Malaysia. Veterinary Parasitology 196, 469-477.

Morley, N.J. \& Lewis, J.W. (2004) Free living endohelminths: influence of multiple factors. Trends in Parasitology 20, 114-115.

Morley, N.J. \& Lewis, J.W. (2013) Thermodynamics of cercarial development and emergence in trematodes. Parasitology 140, 1211-1224.

Morley, N.J. \& Lewis, J.W. (2014) Temperature-related stress and parasitism of endothermic hosts under climate change. Trends in Parasitology 30, 221-227.

Morley, N.J., Crane, M. \& Lewis, J.W. (2003a) Toxicity of cadmium and zinc to the decaudised cercarial life-span of Diplostomum spathaceum (Trematoda: Diplostomidae). Parasitology 127, 497-506.

Morley, N.J., Irwin, S.W. \& Lewis, J.W. (2003b) Pollutant toxicity on the transmission of larval digeneans through their molluscan intermediate hosts. Parasitology 126, S5-26.

Morley, N.J., Crane, M. \& Lewis, J.W. (2004) Influence of cadmium exposure on the incidence of first intermediate host encystment by Echinoparyphium recurvatum cercariae in Lymnaea peregra. Journal of Helminthology 78, 329-332.

Norton, J., Lewis, J.W. \& Rollinson, D. (2003) Parasite infracommunity diversity in eels: a reflection of local component community diversity. Parasitology 127, 475-482.

Norton, J., Lewis, J.W. \& Rollinson, D. (2004) Temporal and spatial patterns of nestedness in eel macroparasite communities. Parasitology 129, 203-211.

Page, A.P., Richards, D.T., Lewis, J.W., Omar, H.M. \& Maizels, R.M. (1991) Comparison of isolates and species of Toxocara and Toxascaris by biosynthetic labelling of somatic and ES proteins from infective larvae. Parasitology 103, 451-464.

Pal, P., Abu-Madi, M.A. \& Lewis, J.W. (2008) Applying an aggregative dispersive dichotomy (ADD) model to parasitic infections in host populations. Journal of Helminthology 82, 187-192.

Pech, D., Aguirre-Macedo, L.M., Lewis, J.W. \& VidalMartínez, V.M. (2010) Rainfall induces time-lagged changes in the proportion of tropical aquatic hosts infected with metazoan parasites. International Journal for Parasitology 40, 937-944.

Richards, D.T., Hoole, D., Lewis, J.W., Ewens, E. \& Arme, C. (1994a) Ultrastructural observations on the cellular response of carp Cyprinus carpio L. to eggs of the blood fluke Sanguinicola inermis Plehn, 1905 (Trematoda: Sanguinicola). Journal of Fish Diseases 17, 439-446.

Richards, D.T., Hoole, D., Lewis, J.W., Ewens, E. \& Arme, C. (1994b) Changes in the cellular composition of the spleen and pronephros of carp Cyprinus carpio infected with the blood fluke Sanguinicola inermis (Trematoda: Sanguinicolidae). Diseases of Aquatic Organisms 19, 173-179.

Richards, D.T., Harris, S. \& Lewis, J.W. (1995) Epidemiological studies on intestinal helminth parasites of rural and urban red foxes (Vulpes vulpes) in the United Kingdom. Veterinary Parasitology 59, 39-51.

Richards, D.T., Hoole, D., Lewis, J.W., Ewens, E. \& Arme, C. (1996a) Adherence of carp leucocytes to adults and cercariae of the blood fluke Sanguinicola inermis. Journal of Helminthology 70, 63-67.

Richards, D.T., Hoole, D., Lewis, J.W., Ewens, E. \& Arme, C. (1996b) In vitro polarization of carp leucocytes in response to the blood fluke Sanguinicola inermis Plehn, 1905 (Trematoda: Sanguinicolidae). Parasitology 112, 509-513.

Sahimin, N., Lim, Y.A.L., Ariffin, F., Behnke, J.M., Lewis, J.W. \& Mohd Zain, S.N. (2016) Migrant workers in Malaysia: current implications of sociodemographic and environmental characteristics in the transmission of intestinal parasitic infections. PLOS Neglected Tropical Diseases 10, 1-17.

Sahimin, N., Lim, Y.A.L., Ariffin, F., Behnke, J.M., Lewis, J.W., Abdullah, K.A. \& Mohd Zain, S.N. (2017) Socio-demographic determinants of Toxoplasma gondii seroprevalence in migrant workers of Peninsular Malaysia. Parasites and Vectors 10, 1-8.

Schludermann, C., Konecny, R., Laimgruber, S., Lewis, J.W., Schiemer, F., Chovanec, A. \& Sures, B. (2003) Fish macroparasites as indicators of heavy metal pollution in river sites in Austria. Parasitology 126, S61-69.

Schuwerack, P.M., Lewis, J.W. \& Jones, P.W. (2001) Pathological and physiological changes in the South African freshwater crab Potamonautes warreni calman induced by microbial gill infestations. Journal of Invertebrate Pathology 77, 269-279.

Scott, M.E. \& Lewis, J.W. (1987) Population dynamics of helminths in wild and laboratory hosts. Mammal Review 17, 95-103.

Vidal-Martinez, V.M., Pal, P., Aguirre-Macedo, M.L., Lewis, J.W. \& May-Tec, A.L. (2014) Temporal variation in the distribution of metazoan parasites of a coastal fish species from the Gulf of Mexico. Journal of Helminthology 88, 112-122. 